\title{
An uptake and elimination kinetics approach to assess the bioavailability of chromium, copper, and arsenic to earthworms (Eisenia andrei) in contaminated field soils
}

\author{
Johanna Kilpi-Koski ${ }^{1}$ (D) - Olli-Pekka Penttinen ${ }^{1} \cdot$ Ari O. Väisänen ${ }^{2} \cdot$ Cornelis A. M. van Gestel $^{3}$
}

Received: 29 September 2018 / Accepted: 18 March 2019 / Published online: 28 March 2019

(C) The Author(s) 2019

\begin{abstract}
The aim of this study was to determine the bioavailability of metals in field soils contaminated with chromated copper arsenate (CCA) mixtures. The uptake and elimination kinetics of chromium, copper, and arsenic were assessed in the earthworm Eisenia andrei exposed to soils from a gradient of CCA wood preservative contamination near Hartola, Finland. In soils contaminated with $1480-1590 \mathrm{mg} \mathrm{Cr} / \mathrm{kg}$ dry soil, $642-791 \mathrm{mg} \mathrm{Cu} / \mathrm{kg}$ dry soil, and $850-2810 \mathrm{mg} \mathrm{Ag} / \mathrm{kg}$ dry soil, uptake and elimination kinetics patterns were similar for $\mathrm{Cr}$ and $\mathrm{Cu}$. Both metals were rapidly taken up and rapidly excreted by Eisenia andrei with equilibrium reached within 1 day. The metalloid As, however, showed very slow uptake and elimination in the earthworms and body concentrations did not reach equilibrium within 21 days. Bioaccumulation factors (BAF) were low for $\mathrm{Cu}$ and $\mathrm{Cr}(<0.1)$, but high for As at 0.54-1.8. The potential risk of CCA exposure for the terrestrial ecosystem therefore is mainly due to As.
\end{abstract}

Keywords Bioavailability · Bioaccumulation - Uptake and elimination kinetics · Metals and metalloids $\cdot$ Eisenia andrei . CCA-contaminated soil

\section{Introduction}

According to a report from the European Soil Data Centre of the European Commission, the estimated number of potentially contaminated sites in Europe is over 2.5 million. Metals (37.3\%) and mineral oil (33.7\%) are the most frequent soil contaminants across Europe (van Liedekerke et al. 2014). In

Responsible editor: Zhihong Xu

Electronic supplementary material The online version of this article (https://doi.org/10.1007/s11356-019-04908-6) contains supplementary material, which is available to authorized users.

Johanna Kilpi-Koski

Johanna.kilpi-koski@ladec.fi

1 Ecosystems and Environment Research Programme, Faculty of Biological and Environmental Sciences, University of Helsinki, Niemenkatu 73, 15140 Lahti, Finland

2 Department of Chemistry, Jyväskylän yliopisto, PL 35, 40014 Jyväskylä, Finland

3 Department of Ecological Science, Faculty of Science, Vrije Universiteit, De Boelelaan 1085, 1081, HV

Amsterdam, The Netherlands
Finland, there are around 24,000 contaminated sites, which include 880 sites used for wood salt impregnation and saw mills (Pyy et al. 2013). Chromated copper arsenate (CCA) was used for more than 60 years in Europe and the USA to preserve wooden structures from moss growth and insect damage (Leduc et al. 2008).

In Finland, the use of metal oxides in wood preservatives began in 1950 with the application of Lahontuho K33 (Viitasaari1991). In Sweden, they were known as Boliden $\mathrm{K} 33$, which became the most widely used CCA formulation. K33 was marketed by many companies around the world under various trade names (Richardson 1993). The CCA compounds are divided into $\mathrm{A}, \mathrm{B}$, and $\mathrm{C}$ type compounds according to the amount of arsenic, but they also differ in solubility (Viitasaari 1991). Until the end of 1982, the CCA wood preservatives used in Finland were of the type B compound. After that, type C compounds were introduced. Until 2003, CCA wood preservatives were the most popular in the wood impregnation worldwide. At our study site in Finland, wood logs were preserved with K-33.

CCA wood preservatives are effective because of the toxicity of copper and arsenic to fungi and insects (Lebow 1996). However, they have been shown to accumulate in the environment under or near CCA-treated wood (Stilwell and Gorny 
1997). Leaching of CCA preservatives into the environment depends on weather conditions and soil characteristics (Balasoiu et al. 2001; Stilwell and Gorny 1997). Reduction of $\mathrm{Cr}$ (VI) to $\mathrm{Cr}(\mathrm{III})$ is the main driver of a series of reactions in the fixation of CCA complexes, resulting in the insolubilization of CCA. Fixation reactions reduce the leachability of $\mathrm{Cu}$, $\mathrm{Cr}$, and $\mathrm{As}$ into the environment but environmental factors like $\mathrm{pH}$ and temperature may also affect leachability of these metals (Hingston et al. 2001). The leached CCA metals are expected to adsorb quickly to soil particle surfaces, but may be desorbed into the soil solution after rainfall or irrigation events (Leduc et al. 2008). CCA leaching generally increases with the age of CCA handled timber (Katz and Salem 2005). As a consequence, many terrestrial and aquatic ecosystems are contaminated with leachates of CCA-treated wood.

Little is known about the bioavailability of CCA metals in mixtures, and therefore great uncertainty exists about their potential risk in soils. Measures of bioavailability can be used as a guideline for the risk assessment of soil contamination (Peijnenburg et al. 1997, 1999). Bioavailability of metals is a complicated issue as it depends on the metal itself, the exposed biological species and its ability to regulate metal uptake and excretion, and the environmental compartment where the organism lives (Peijnenburg and Jager 2003). Additionally, the organism's size, receptor(s), specific pathophysiological characteristics, the metal's route of entry, the duration and frequency of exposure, the dose and the exposure matrix may also impact bioavailability (Allen et al. 2002). Soil properties like $\mathrm{pH}$ (van Gestel and Hensbergen 1997), redox potential (Masscheleyn et al. 1991), clay content (Lin and Puls 2000), Ca concentration, and organic matter content may affect the bioavailability of metals, their kinetics of uptake and elimination in organisms, and the development of body concentrations with time (Vijver et al. 2003). Since the toxicity of metals depends on the concentration in the body, uptake and elimination kinetics are important and relevant tools for evaluating the bioavailability of metals.

Long-term contaminated sites may contain many contaminants forming complex mixtures. Metal mixture contamination is different from single metal contamination as different metals may have different kinetics, which will lead to differences in metal concentration ratios in the body compared with external concentrations in exposed organisms. In the mixtures, metal concentration ratios in the body are crucial for determining and understanding toxicity.

The aim of this study was to determinate the bioavailability of chromium, copper, and arsenic to earthworms along a concentration gradient to provide a basis for the ecotoxicological risk assessment of CCA-contaminated field soils. Earthworms are a suitable organism for uptake-elimination kinetic experiments because they have direct contact with the soil and its different compartments. They are also important organisms for soil ecology and its systems (Peijnenburg et al. 1997). We used OECD guideline 317 (OECD 2010) for determining metal uptake and elimination kinetics in earthworms. Our hypotheses were that the uptake kinetics in Eisenia andrei are different for $\mathrm{Cr}, \mathrm{Cu}$, and $\mathrm{As}$, and do provide insight into the bioavailability of these metals in CCAcontaminated soils.

\section{Materials and methods}

\section{Study site}

The study area was an old wood impregnation site located in Hartola, Southern Finland. In an area measuring $100 \mathrm{~m} \times$ $150 \mathrm{~m}, \mathrm{~K}-33$ liquid diluted with water was sprayed with pressure into two impregnation tubes of $12 \mathrm{~m} \times 30 \mathrm{~cm}$ and one of $16 \mathrm{~m} \times 3.1 \mathrm{~m}$. At the site, wood logs were preserved with $\mathrm{K}-33$, which contained $34.0 \% \mathrm{As}(\mathrm{V}) \mathrm{Oxide}, 26.6 \% \mathrm{Cr}_{2} \mathrm{O}_{3}$, $14.8 \% \mathrm{CuO}$, and $24.6 \%$ water. During the period 1958 1966, approximately 2500 wood logs were preserved per year, using 8400 L K-33 liquid annually. After treatment, the wood logs were dried in the area for 3 days. When finishing impregnation actions in autumn, leftover wood impregnation liquid was discarded by pouring onto the soil, leading to contamination of the soil and ground water. At the study site, the pseudo total concentrations of CCA metals in the soil $(\mathrm{mg} / \mathrm{kg})$ were as follows: $\mathrm{Cr}$ 12.5-1592, As 10.1-2812, and $\mathrm{Cu}$ 5.1-79. In Finland, the background levels and the range $(\mathrm{mg} / \mathrm{kg})$ for Chromium, Arsenic, and Copper are 31 (6-170), 1 (0.1-25), and $22(5-110)$, respectively (Finnish Government decree 214/2007). A detailed description of the Hartola study site has been given by Karjalainen et al. (2009).

\section{Soil sampling}

Humus soil for the experiment was collected from a 60 year-old Norway spruce (Picea abies L.) stand of OxalisMyrtillus site type (Cajander 1949) from Hartola, Southern Finland $\left(68^{\circ} 17^{\prime} 820 \mathrm{~N} / 34^{\circ} 44^{\prime} 030 \mathrm{E}\right)$. The study site $(100 \mathrm{~m} \times 150 \mathrm{~m})$ was divided into four sampling areas based on a concentration gradient, being classified as high (H), medium (M), low (L), and control (C) areas (Figure S1 in the Supporting Information). Pre-concentration analysis for $\mathrm{Cr}, \mathrm{Cu}$, and $\mathrm{As}$ was done on site with a field-portable $\mathrm{X}$ ray fluorescence meter (XRF) (Karjalainen et al. 2009). In each sampling area, five squares $(1.5 \mathrm{~m} \times 1.5 \mathrm{~m})$ were laid out from each of which two samples, each of $1 \mathrm{~kg}$, were collected and pooled together. The samples were taken from the humus layer. The depth of the humus layer was $2.5 \mathrm{~cm}$ in the highly polluted area, $3.8 \mathrm{~cm}$ for medium, $4.1 \mathrm{~cm}$ for low, and $5.1 \mathrm{~cm}$ in the control area. 


\section{Soil analyses}

Soil water holding capacity (WHC) was determined following ISO (1999). Organic matter content (OM) was determined as loss on ignition at $550^{\circ} \mathrm{C}$ for $4 \mathrm{~h}$. Soil $\mathrm{pH}$ was measured from $\mathrm{H}_{2} \mathrm{O}$ and $0.01 \mathrm{M} \mathrm{CaCl}_{2}$ extracts (soil to liquid ratio, 1:10; shaken for $2 \mathrm{~h}$ at $200 \mathrm{rpm}$ ) with a SCHOTT $\mathrm{pH}$ meter, type CG842. Soil moisture content was determined by drying soil samples at $105{ }^{\circ} \mathrm{C}$ for $24 \mathrm{~h}$. Particle size distribution was determined using laser size grain analysis, which is based on the forward scattering of monochromatic coherent light as described by Konert and Vandenberghe (1997).

\section{Uptake/elimination experiment}

For the metal uptake and elimination experiment, earthworms (Eisenia andrei) were exposed to contaminated soils from the four test sites: high (H), medium (M), low (L), and control (C). Each soil had six replicates per sampling time. One earthworm was placed in a glass container containing $35-50 \mathrm{~g}$ of test soil (ww). The earthworms were taken from a synchronized culture at the Vrije Universiteit, Amsterdam, The Netherlands. Only adults with a well-developed clitellum were used. Before starting exposures, the earthworms were acclimatized in OECD artificial soil (OECD 1984) for $24 \mathrm{~h}$ at $20 \pm 1{ }^{\circ} \mathrm{C}$. OECD artificial soil was used as a control. A small amount of horse dung ( $2 \%$ of the dry soil mass) was mixed in with the test soils for food for the earthworms. Soil moisture content was adjusted to $50 \%$ of the WHC. The test containers were loosely covered with a lid, and incubated in climate chambers at $20 \pm 1{ }^{\circ} \mathrm{C}$ with a light:dark cycle of $16 / 8 \mathrm{~h}$.

In the uptake phase, six replicate earthworms were sampled at days $0,0.5,1,4,8,15$, and 21 . After 21 days, the remaining earthworms were taken from their respective soils, rinsed with water, and transferred to OECD artificial soil for the elimination phase. Similarly, during the elimination period, six replicate earthworms were sampled at days $0.5,1,2,4,8,15$, and 21. Sampled earthworms were rinsed with water to remove adhering soil particles, placed on moist filter paper to void their gut for $24 \mathrm{~h}$, weighed, frozen, and freeze-dried for metal analysis.

\section{Metal analysis}

\section{Pseudo total metal concentrations in the soils}

About $500 \mathrm{mg}(\mathrm{dw})$ soil was weighed into $50-\mathrm{mL}$ plastic bottles and $10 \mathrm{~mL}$ aqua regia $\left(\mathrm{HCl}: \mathrm{HNO}_{3}, 3: 1\right)$ was added. The acids ( $\mathrm{HCl} 36.5-38.0 \%$ and $\mathrm{HNO}_{3}$ 69.0-70.0\%) were supplied by J.T. Baker for trace metal analysis. After closing, the bottles were placed in an ultrasonic bath (Transsonic 820/ $\mathrm{H}$ Elma ${ }^{\circledR}$ ) for $3 \times 3 \mathrm{~min}$ at a temperature of about $45-50{ }^{\circ} \mathrm{C}$. After sonification and cooling, the samples were filtered
(Whatman no. 41) into a $25-\mathrm{mL}$ volumetric glass bottle, diluted with high purity ELGA water to a volume of $25 \mathrm{~mL}$, and stored in plastic bottles for the analysis with Inductively Coupled Plasma-Optical Emission Spectrometry (ICP-OES; Perkin-Elmer Optima 4300DV). All equipment was rinsed with acid before use. Reference materials for contaminated soils, SRM 2710 and SRM 2711, both certified by the National Institute of Standards and technology (NIST), were included in the analysis. Recoveries from the certified reference sample SRM 2710 were $96 \%$ for As and $92 \%$ for $\mathrm{Cu}$; recovery of $\mathrm{Cu}$ from the reference material SRM 2711 was $96 \%$. No certified reference values were given for $\mathrm{Cr}$ concentration in the SRM 2710 sample. The procedure has been described by Väisänen et al. (2002). Detection limits for pseudo total concentrations of $\mathrm{Cr}, \mathrm{Cu}$, and As were 0.3, 0.4, and $2 \mathrm{mg} / \mathrm{kg}$ dry soil.

\section{Extractable metals}

To determine available metal concentrations, the test soils were extracted with $\mathrm{H}_{2} \mathrm{O}$ and $0.01 \mathrm{M} \mathrm{CaCl}_{2}$. About $5 \mathrm{~g}$ moist test soil was extracted with $50 \mathrm{~mL} \mathrm{H}_{2} \mathrm{O}$ or $50 \mathrm{~mL} 0.01 \mathrm{M}$ $\mathrm{CaCl}_{2}$ by shaking for $2 \mathrm{~h}$ at $200 \mathrm{rpm}$. After settling overnight, $\mathrm{pH}$ was measured, and samples were $0.45-\mu \mathrm{m}$-filtered and preserved with $\mathrm{HNO}_{3}$ for analyzing extractable metal concentrations (Smit et al. 1997) with ICP-OES. Detection limits for $0.01 \mathrm{M} \mathrm{CaCl}_{2}$-extractable concentrations were $0.03,0.04$, and $0.2 \mathrm{mg} / \mathrm{kg}$ dry soil and for $\mathrm{H}_{2} \mathrm{O}$-extractable, $0.08,0.13$, and $0.7 \mathrm{mg} / \mathrm{kg}$ dry soil, respectively.

\section{Metal concentrations in Eisenia andrei}

The earthworms were digested individually in $4 \mathrm{~mL}$ aqua regia $\left(3 \mathrm{HCl}: 1 \mathrm{HNO}_{3}\right)$. Earthworm samples were placed for $1 \mathrm{~h}$ in a water bath at $70-80^{\circ} \mathrm{C}$. After cooling, the extract was filtered and diluted with high purity ELGA water to a volume of $25 \mathrm{~mL}$ (Lukkari et al. 2004). The samples were analyzed for metal concentrations by ICP-OES (Perkin-Elmer (Norwalk, CT, USA) model Optima 4300 DV) as described by Väisänen et al. (2002). A Scott-type double-pass spray chamber and a cross-flow nebulizer were used throughout. The determination of metal concentrations was performed using default parameters of the instrument (nebulizer flow $0.6 \mathrm{~L} \mathrm{~min}^{-1}$, auxiliary gas flow $0.2 \mathrm{~L} \mathrm{~min}^{-1}$, plasma gas flow $15 \mathrm{~L} \mathrm{~min}^{-1}$, and plasma power of $1400 \mathrm{~W}$ ). The wavelengths with the axial plasma viewing used in the determination were $193.696 \mathrm{~nm}, 283.563 \mathrm{~nm}$, and $324.752 \mathrm{~nm}$ for $\mathrm{As}, \mathrm{Cr}$, and $\mathrm{Cu}$, respectively. Quality control was performed by the analysis of two certified reference materials, DOLT-4 Dogfish liver and TORT-2 Lobster hepatopancreas. High recoveries were obtained for all the elements of interest. The certified and measured concentrations $(\mathrm{mg} / \mathrm{kg})$ and recoveries of metals $(\%)$ from the DOLT-4 Dogfish liver were as follows: As 9.66 \pm 
$0.62,7.75 \pm 0.08$, and 80.2; $\mathrm{Cu} 31.2 \pm 1.1,30.3 \pm 0.4$, and 97.1; Cr 1.4 (stated value, not certified), $1.4 \pm 0.4$, and 100 . The certified and measured concentrations $(\mathrm{mg} / \mathrm{kg})$ and metal recoveries (\%) from the TORT-2 Lobster hepatopancreas were as follows: As 21.6 $\pm 1.8,22.9 \pm 0.3$, and 105.8; $\mathrm{Cu} 106 \pm 10$, $97 \pm 2$, and 92 , and $\operatorname{Cr} 0.77 \pm 0.15,1.0 \pm 0.2$, and 130 , respectively.

\section{Kinetics model}

A one-compartment model was applied to describe the uptake (Eq. 1) and elimination (Eq. 2) kinetics of chromium, copper, and arsenic in the earthworms exposed to the Hartola soils (Atkins 1969).

$$
\begin{aligned}
C_{\text {worm }}= & C_{0}+\frac{k 1}{k 2} \times C_{\exp 1} \times\left(1-e^{-k_{2} t}\right) \\
C_{\text {worm }}= & C_{0}+\frac{k 1}{k 2} \times C_{\exp 1} \times\left(1-e^{-k_{2} t}\right)+\frac{k_{1}}{k_{2}} \times C_{\exp 1} \\
& \times\left(1-e^{-k_{2}\left(t-t_{x}\right)}\right)
\end{aligned}
$$

where $C_{\text {worm }}$ is the internal copper/chromium/arsenic concentration in the earthworms at time $t$ ( $\mathrm{mg} / \mathrm{kg}$ dry body weight), $C_{0}$ is the initial (background) copper/chromium/arsenic concentration in the earthworms at $t=0$ ( $\mathrm{mg} / \mathrm{kg}$ dry body weight), $k_{1}$ is the uptake rate constant ( $\mathrm{kg}$ soil $/ \mathrm{kg}$ earthworm/day), $k_{2}$ is the elimination rate constant $\left(\right.$ day $\left.^{-1}\right), C_{\exp 1}$ is the copper/chromium/arsenic exposure concentration during the uptake phase ( $\mathrm{mg} / \mathrm{kg}$ dry soil), $t$ is the exposure time (days), and $t_{x}$ is the day on which animals were transferred to clean OECD artificial soil (day 21). Both Eqs. 1 and 2 were fitted together to obtain single values for the uptake and for the elimination rate constants. Microsoft Excel 2010 was used to fit the onecompartment model to the data for each study site and metal, and IBM SPSS Statistics 21 to estimate the standard errors and other statistical parameters of the estimated uptake and elimination rate constants. The bioaccumulation factor (BAF) for the accumulation of the metals in E. andrei was estimated using the following equation (Sharma et al. 2011): $B A F=\frac{k_{1}}{k_{2}}$

\section{Results}

The CCA-contaminated field soils from Hartola were acidic with $\mathrm{pH}_{\mathrm{CaCl} 2}$ between 3.4 and 4.5 and $\mathrm{pH}_{\mathrm{H} 2 \mathrm{O}}$ between 4.3 and 5.7 (Table 1). Organic matter contents (OM) were high, ranging from 21 to $32 \%$, and soils were sandy with low clay content. Water holding capacity (WHC) of the study soils was high, with 238-325\%. Moisture contents ranged from 41.6 to $93.8 \%$.
Pseudo total concentrations ( $\mathrm{mg} / \mathrm{kg}$ ) of chromium and copper in the high and medium contaminated areas were similar, while they were low in the low contaminated and control areas (Table 2). Total As concentration was highest in the high contaminated soil. Water and $0.01 \mathrm{M} \mathrm{CaCl}_{2}$ extractable metal concentrations were below the detection limit for the control and low contaminated soils. For $\mathrm{Cr}$ and As, water-extractable concentrations in the high and medium contaminated soils were slightly higher than the $\mathrm{CaCl}_{2}$ extractable concentrations. For copper, the difference between water- and $\mathrm{CaCl}_{2}$ extractable concentrations in these soils was small and not consistent (Tables 2).

Earthworm survival was high during the 42-day experimental period, with only 3 animals dying in the control (83 worms) and 2, 7, and 11 dead worms out of 83 in low, medium, and high contaminated soils, respectively.

In the low contaminated soil, no uptake of chromium, copper, and arsenic was seen, with earthworm body concentrations remaining more or less constant at approximately 0.9 , 7.7 , and $22 \mathrm{mg} / \mathrm{kg}$ body weight, respectively throughout the uptake and elimination phases (Fig. 1). In the medium and high contaminated soils, chromium and copper showed very fast uptake and elimination kinetics in the earthworms. Equilibrium was reached within a day, and after transfer of the earthworms to clean soil, $\mathrm{Cr}$ and $\mathrm{Cu}$ body concentrations returned to the background level also within 1 day. Arsenic, however, showed very slow uptake and elimination kinetics in the earthworms exposed to the medium and high contaminated soil. Steady state was not reached within 21 days of exposure (Fig. 1).

There was little difference between $\mathrm{Cr}$ and $\mathrm{Cu}$ uptake $\left(k_{1}\right)$ and elimination $\left(k_{2}\right)$ rate constants for medium and high contaminated soils, and they were indicating very fast kinetics. For As, $k_{1}$ and $k_{2}$ in both the high and medium contaminated soils were very small, indicating slow kinetics. Bioaccumulation factors (BAF) were well below 0.1 for $\mathrm{Cr}$ and $\mathrm{Cu}$, but between 0.54 and 1.8 for As, and did not differ much for the medium and high contaminated soils.

Calculating uptake rate constants $\left(k_{1}\right)$ based on water- or $\mathrm{CaCl}_{2}$-extractable concentrations (Tables S1 and S2) did slightly decrease the difference between medium and high contaminated soils for $\mathrm{Cr}$ but not for $\mathrm{Cu}$ and $\mathrm{As}$.

\section{Discussion}

The main objective of this study was determining the bioavailability of chromium $(\mathrm{Cr})$, copper $(\mathrm{Cu})$, and arsenic (As) to the earthworm $E$. andrei along a gradient of metal pollution, applying a toxicokinetics approach. Test soils were taken from a gradient of $\mathrm{Cr}, \mathrm{Cu}$, and As contamination in a Finish forest field soil contaminated several decades with a chromated copper arsenate (CCA) wood preservative. In an earlier study, 
Table 1 Properties of the CCA-contaminated soils from Hartola, Finland. Shown are mean values with standard deviation; OM organic matter, WHC water holding capacity

\begin{tabular}{lllllllll}
\hline Site & $\begin{array}{l}\mathrm{pH}_{\mathrm{CaCl} 2} \\
(n=3)\end{array}$ & $\begin{array}{l}\mathrm{pH}_{\mathrm{H} 2 \mathrm{O}} \\
(n=3)\end{array}$ & $\begin{array}{l}\% \mathrm{OM} \\
(n=3)\end{array}$ & $\begin{array}{l}\text { WHC } \\
(n=10)\end{array}$ & $\begin{array}{l}\text { Moisture content } \\
(\%)(n=5)\end{array}$ & $\begin{array}{l}\% \text { clay }(<8 \mu \mathrm{m}) \\
(n=5)\end{array}$ & $\begin{array}{l}\% \text { silt }(8-64 \mu \mathrm{m}) \\
(n=5)\end{array}$ & $\begin{array}{l}\% \text { sand }(64-2000 \mu \mathrm{m}) \\
(n=5)\end{array}$ \\
\hline Control & $3.39 \pm 0.05$ & $4.30 \pm 0.10$ & $30.8 \pm 2.63$ & $325 \pm 77$ & $49.6 \pm 2.94$ & $5.1 \pm 1.6$ & $11.1 \pm 1.7$ & $83.7 \pm 3.3$ \\
Low & $3.89 \pm 0.01$ & $4.95 \pm 0.10$ & $23.9 \pm 6.62$ & $271 \pm 124$ & $50.5 \pm 9.62$ & $4.1 \pm 0.8$ & $10.3 \pm 0.8$ & $85.6 \pm 1.6$ \\
Medium & $4.32 \pm 0.07$ & $5.53 \pm 0.02$ & $31.8 \pm 4.23$ & $277 \pm 56$ & $93.8 \pm 11.6$ & $4.8 \pm 0.6$ & $12.6 \pm 1.6$ & $82.6 \pm 1.8$ \\
High & $4.53 \pm 0.08$ & $5.68 \pm 0.07$ & $20.8 \pm 5.50$ & $238 \pm 105$ & $41.6 \pm 11.2$ & $3.1 \pm 2.7$ & $6.5 \pm 1.7$ & $90.4 \pm 4.2$ \\
\hline
\end{tabular}

Karjalainen et al. (2009) indicated that pollution levels in this area may be hazardous to the terrestrial ecosystem. In the present study, we found two different uptake-elimination patterns in $E$. andrei. Uptake rate constant $k_{1}$ and elimination rate constant $k_{2}$ were high indicating fast kinetics for $\mathrm{Cu}$ and $\mathrm{Cr}$, but were very low showing very slow kinetics for As. These differences may be caused by differences in the bioavailability of the metals and their metabolic routes in earthworms.

\section{Metal availability}

Variation of bioavailability and accumulation has been studied for different chemicals and earthworm species and using different experimental designs and analytical platforms (Spurgeon et al. 2011). These studies have shown a difference in bioavailability between artificial soils (like OECD) and field soils (Peijnenburg et al. 1999). Metals are more bioavailable in freshly spiked artificial soils than in field-contaminated soils (Spurgeon and Hopkin 1995). Pseudo total concentrations $(\mathrm{mg} / \mathrm{kg}, \mathrm{dw})$ of $\mathrm{Cu}, \mathrm{Cr}$, and $\mathrm{As}$ in the medium and high CCA field-contaminated soils (Table 2) were 6-8, 15-16, and 17-56 times higher than the Finnish lower limit values, respectively. Although pseudo total metal concentrations were high, similar to e.g., Hagner et al. (2017), this did not translate into high available concentrations in $\mathrm{H}_{2} \mathrm{O}$ and $0.01 \mathrm{M} \mathrm{CaCl}_{2}$ extracts. This was expected because the field soil was contaminated decades ago. The metal contaminant pool requires time to diffuse into micro or nanopores and to be absorbed into organic matter and adsorbed onto soil particles (Allen et al. 2002). This aging process, which usually is nearly completed within 1 year of spiking the metals, makes a direct and straightforward comparison of metal bioavailability in OECD artificial and field soils challenging (Peijnenburg et al. 1999).

In this study, the bioavailability of $\mathrm{Cu}, \mathrm{Cr}$, and As metals and their partitioning in the field-contaminated soils were influenced by soil properties like soil $\mathrm{pH}$, organic matter, and clay content. The CCA-contaminated field soils were acidic $\left(\mathrm{pH}_{\mathrm{CaCl} 2} 3.4-4.5\right)$, which has influenced speciation and mobility of the metals present. Under acidic conditions, the toxic and mobile $\mathrm{Cr}(\mathrm{VI})$ will be reduced to the stable and less toxic Cr(III) (Kumpiene et al. 2008; Sivakumar and Subbhuraam 2005). In soil, copper is bound to organic matter. When $\mathrm{pH}$ increases the sorption of the free $\mathrm{Cu}^{2+}$, ion on solid organic matter increases (Degryse et al. 2009) and $\mathrm{Cu}$ also becomes more strongly bound to oxide surfaces (Khaodhiar et al. 2000). Peijnenburg et al. (1999) did not observe significant uptake of arsenic in earthworms at $\mathrm{pH}_{\mathrm{CaCl} 2}<6$ and at $\mathrm{pH}_{\mathrm{CaCl} 2}>6.75$. At low $\mathrm{pH}$ and high redox potential, As is mainly in the $\mathrm{As}(\mathrm{V})$ form, but when $\mathrm{pH}$ increases and redox potential decreases, As(III) is the dominant form in soils (Masscheleyn et al. 1991) and in earthworms (Lee and Kim 2013). Soil acidity was found to be the most important solid-phase characteristic modulating the availability of As and its sorption (Balasoiu et al. 2001; Peijnenburg et al. 1999). All these studies support our findings of low $\mathrm{H}_{2} \mathrm{O}$ - and $0.01 \mathrm{M} \mathrm{CaCl}_{2}$-extractable concentrations of $\mathrm{Cr}, \mathrm{Cu}$, and $\mathrm{As}$ in the acidic and high organic CCA-contaminated field soils from Hartola.

Many studies have shown that metals bind to organic matter and, as a consequence, are not available for uptake. $\mathrm{Cr}, \mathrm{Cu}$,

Table 2 Mean $( \pm \mathrm{SD})$ pseudo total, water, and $0.01 \mathrm{M} \mathrm{CaCl}_{2}$ extractable concentrations $[\mathrm{mg} / \mathrm{kg}$ dry soil] of chromium $(\mathrm{Cr})$, copper $(\mathrm{Cu})$, and arsenic (As) in the CCA-contaminated soils from Hartola, Finland, used for the toxicokinetics experiment with Eisenia andrei

\begin{tabular}{|c|c|c|c|c|c|c|c|c|c|}
\hline \multirow[t]{2}{*}{ Study site } & \multicolumn{3}{|c|}{ Pseudo total $[\mathrm{mg} / \mathrm{kg}](n=37-39)$} & \multicolumn{3}{|c|}{$\mathrm{H}_{2} \mathrm{O}$ extractable $[\mathrm{mg} / \mathrm{kg}](n=3)$} & \multicolumn{3}{|c|}{$\mathrm{CaCl}_{2}$ extractable $[\mathrm{mg} / \mathrm{kg}](n=3)$} \\
\hline & $\mathrm{Cr}$ & $\mathrm{Cu}$ & As & $\mathrm{Cr}$ & $\mathrm{Cu}$ & As & $\mathrm{Cr}$ & $\mathrm{Cu}$ & As \\
\hline Control (C) & $5.34 \pm 1.68$ & $4.71 \pm 1.06$ & $6.12 \pm 1.22$ & $<$ & $0.21 \pm 0.11$ & $0.20 \pm 0.11$ & $<$ & $<$ & $3.54 \pm 0.09$ \\
\hline Low (L) & $12.5 \pm 10.6$ & $5.14 \pm 5.3$ & $10.1 \pm 5.5$ & $<$ & $0.19 \pm 0.04$ & $0.17 \pm 0.03$ & $<$ & $<$ & $3.43 \pm 0.11$ \\
\hline Medium (M) & $1590 \pm 247$ & $791 \pm 140$ & $850 \pm 225$ & $4.72 \pm 0.38$ & $2.95 \pm 0.24$ & $9.98 \pm 0.62$ & $0.84 \pm 0.16$ & $4.58 \pm 0.23$ & $7.67 \pm 0.29$ \\
\hline $\operatorname{High}(\mathrm{H})$ & $1480 \pm 355$ & $642 \pm 180$ & $2810 \pm 921$ & $13.5 \pm 0.33$ & $6.23 \pm 0.13$ & $54.5 \pm 1.94$ & $2.55 \pm 0.39$ & $2.22 \pm 0.26$ & $20.8 \pm 2.54$ \\
\hline
\end{tabular}

$<$, below detection limit 

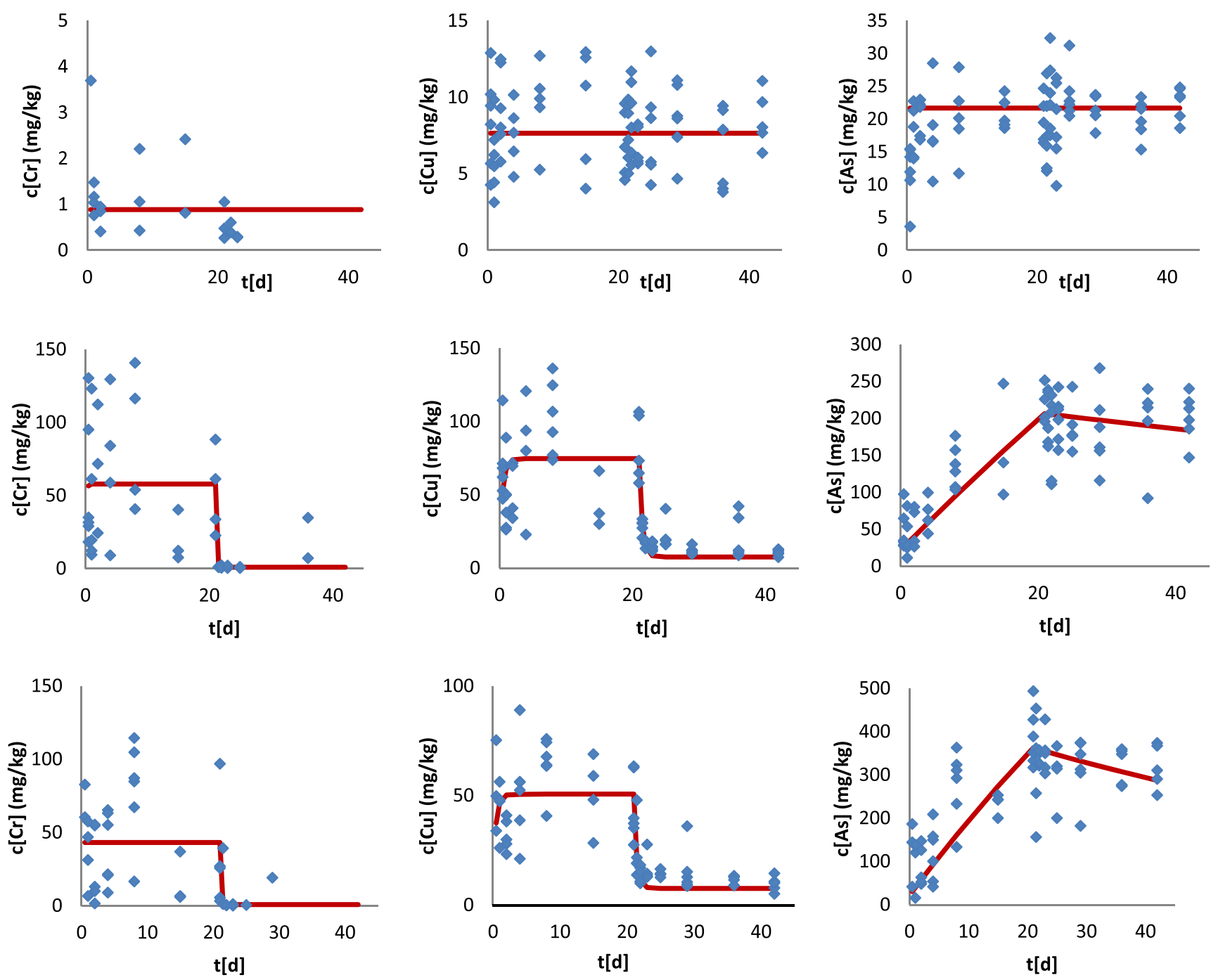

Fig. 1 Uptake and elimination kinetics of chromium (left), copper (middle), and arsenic (right) in earthworms (Eisenia andrei) exposed for 21 days to low (top), medium (middle), and high (bottom) CCAcontaminated field soils from the site near Hartola, Finland, followed

by a 21-day elimination phase in clean OECD artificial soil. Lines show the fit of a one-compartment model to the data (Eqs. 1 and 2). Table 3 shows the corresponding uptake and elimination rate constants.

and As all have high affinity for binding to soil organic matter (Meharg et al. 1998; Peijnenburg et al. 1999; Marinussen et al. 1997; Speir et al. 1995). In this study, organic matter contents

Table 3 Kinetics parameters ( \pm SE) for the uptake and elimination of $\mathrm{Cr}, \mathrm{Cu}$, and $\mathrm{As}$ in the earthworm Eisenia andrei following exposure to CCA field-contaminated soils from Hartola, Finland. Kinetics parameters were derived by relating metal concentrations in the earthworms to pseudo total concentrations in the test soils. $k_{1}$ is the uptake rate constant, $k_{2}$
(OM) were high, ranging between 21 and $32 \%$, while the Hartola soils were sandy with low clay content. Balasoiu et al. (2001) concluded that $\mathrm{Cu}$ was bound to organic matter

the elimination rate constant, and BAF is bioaccumulation factor. A onecompartment model was used to estimate kinetics parameters, using Eq. 1 for uptake and Eq. 2 for elimination phase data. See Fig. 1 for the corresponding data and model fits

\begin{tabular}{|c|c|c|c|c|c|c|c|c|c|}
\hline \multirow[t]{2}{*}{ Site } & \multicolumn{3}{|c|}{$k_{1}(\mathrm{~kg}$ soil/kg worm/day) } & \multicolumn{3}{|c|}{$k_{2}\left(\right.$ day $\left.^{-1}\right)$} & \multicolumn{3}{|l|}{ BAF } \\
\hline & $\mathrm{Cr}$ & $\mathrm{Cu}$ & As & $\mathrm{Cr}$ & $\mathrm{Cu}$ & As & $\mathrm{Cr}$ & $\mathrm{Cu}$ & As \\
\hline Low & - & - & - & - & - & - & - & - & - \\
\hline Medium & $0.27 \pm 0.68$ & $0.19 \pm 0.042$ & $0.011 \pm 0.0091$ & $7.6 \pm 19$ & $2.2 \pm 0.52$ & $0.0062 \pm 0.0048$ & 0.036 & 0.086 & 1.8 \\
\hline High & $0.71 *$ & $0.16 \pm 0.043$ & $0.0065 \pm 0.00055$ & $24.6^{*}$ & $2.4 \pm 0.65$ & $0.012 \pm 0.0052$ & 0.029 & 0.067 & 0.54 \\
\hline
\end{tabular}

*Very large SE 
because of suitable reactive groups and retained by complexation rather than ion exchange. Chromium partitioning to organic matter was similar to that of copper (Balasoiu et al. 2001). In high organic soils, $\mathrm{Cr}$ and $\mathrm{Cu}$ are present in less mobile and less available forms (Balasoiu et al. 2001; Gupta et al. 1996; Maiz et al. 2000). Also, As has high affinity for binding to soil organic matter (Meharg et al. 1998). These findings may explain the low $\mathrm{H}_{2} \mathrm{O}$ and $\mathrm{CaCl}_{2}$ extractable concentrations in our test soils (Table 2). In our test soils, the available concentrations of $\mathrm{Cr}, \mathrm{Cu}$, and As were very low in the low contaminated soil, and in general, less than $1 \%$ of the metal was available in the medium and high contaminated soils, except for the water extractability of As which was 1$2 \%$. The slightly higher metal availability in the high contaminated soil compared with the medium contaminated soil (Table 2) can be attributed to the higher organic matter and clay content of the latter. The fact that for $\mathrm{Cr}$ and As waterextractable concentrations were higher than $\mathrm{CaCl}_{2}$-extractable concentrations suggests that these elements were not present as cations in the CCA-contaminated field soils.

\section{Uptake-elimination kinetics of chromium and copper}

In the present study, differences in $\mathrm{H}_{2} \mathrm{O}$ or $0.01 \mathrm{M} \mathrm{CaCl}_{2}$ extractability did not translate into differences in uptake kinetics in the earthworms. $\mathrm{Cr}$ and $\mathrm{Cu}$ accumulated very rapidly in $E$. andrei and steady-state concentrations were reached within 1 day of exposure. Peijnenburg et al. (1999) found similar patterns for $\mathrm{Cr}$ and $\mathrm{Cu}$. Internal steady-state concentrations (day 21) in E. andrei exposed to the medium and high contaminated soils were 88.2 and $97.1 \mathrm{mg} / \mathrm{kg} \mathrm{dw}$, respectively for $\mathrm{Cu}$, and 106 and $63.6 \mathrm{mg} / \mathrm{kg} \mathrm{dw}$, respectively for Cr. van Gestel et al. (1993) exposed E. andrei for 3 weeks to $\mathrm{Cr}$ concentrations of $0,10,32,100$, 320 , and $1000 \mathrm{mg} / \mathrm{kg}$ dry soil in freshly spiked OECD artificial soil and found tissue concentrations in the earthworms of $0.8-18 \mathrm{mg} / \mathrm{kg} \mathrm{dw}$. In Dutch field soils, containing total concentrations of 3.2-988 $\mathrm{mg} \mathrm{Cr} / \mathrm{kg}$ dry soil and $1.1-108 \mathrm{mg} \mathrm{Cu} /$ $\mathrm{kg}$ dry soil, steady-state concentrations in E. andrei were $1.04-14.0 \mathrm{mg} \mathrm{Cr} / \mathrm{kg} \mathrm{dw}$ and 5.72-34.4 $\mathrm{mg} \mathrm{Cu} / \mathrm{kg} \mathrm{dw}$ (Peijnenburg et al. 1999). Following exposure to fieldcontaminated soils from the UK, containing total concentrations of 725 and $1732 \mathrm{mg} \mathrm{Cu} / \mathrm{kg}$ dry soil, tissue concentrations in Lumbricus rubellus were 44.1 and $85.3 \mathrm{mg} \mathrm{Cu} / \mathrm{kg} \mathrm{dw}$ (Langdon et al. 2001). The latter findings are similar to the values obtained in the present study, but the levels of $\mathrm{Cr}$ in soils and E. andrei in the studies of van Gestel et al. (1993) and Peijnenburg et al. (1999) are lower than in the present study. The differences between studies can be explained by differences in $\mathrm{pH}$ and organic matter content of the field soils (Langdon et al. 2001; Peijnenburg et al. 1999), and the use of (freshly spiked) artificial soil (van Gestel et al. 1993).
In the medium $(\mathrm{M})$ and high $(\mathrm{H})$ contaminated soils, fast uptake kinetics of chromium and copper with fast elimination rates were seen in the earthworm $E$. andrei. The absence of clear differences between the two soils might be due to the fact that these soils had very similar pseudo total metal concentrations. Uptake rate constants $k_{1}$ for $\mathrm{Cr}$ in medium and high soils were 0.27 and $0.71 \mathrm{~kg}$ soil $/ \mathrm{kg}$ worm $/$ day, respectively, and for $\mathrm{Cu}, 0.19$ and $0.16 \mathrm{~kg}$ soil $/ \mathrm{kg}$ worm/day, respectively. Equilibrium was reached within a day and after transfer of the earthworms to clean OECD soil, they reached the background level also within 1 day. Nahmani et al. (2009) found similar uptake rate constants $k_{1}(0.16-0.57 \mathrm{~kg}$ soil/ $\mathrm{kg}$ worm/day) for $\mathrm{Cu}$ in different UK field soils. In our study, very fast elimination of $\mathrm{Cr}$ and $\mathrm{Cu}$ from $E$. andrei occurred with $k_{2}=7.6-24.6$ and 2.2-2.4 day $^{-1}$, respectively. These $k_{2}$ values agree with the data of Peijnenburg et al. (1999), Spurgeon and Hopkin (1999), and van Gestel et al. (1993). Nahmani et al. (2009) found the opposite effect for the elimination of $\mathrm{Cu}$. Compared with their soils, our field soils had higher organic matter contents and were more acidic.

Why are uptake and elimination patterns of $\mathrm{Cu}$ and $\mathrm{Cr}$ similar? $\mathrm{Cr}$ may be mimicking the essential metal $\mathrm{Cu}$. $\mathrm{Cr}$ also is an essential nutrient playing a role in the release of insulin from tissues when needed for the usage of sugars, proteins, and fats (Shrivastava et al. 2002). In acidic environments, $\mathrm{Cu}$ and $\mathrm{Cr}$ occur as cations $\left(\mathrm{Cu}^{2+}\right.$ and $\left.\mathrm{Cr}^{3+}\right)$. Their size is similar and they have very similar chemical characteristics. Both are Lewis acids which bind strongly to organic matter forming similar type organic ligands, which may explain why these two metals have similar uptake and elimination patterns in E. andrei like other essential metals. Fast uptake reaching equilibrium within a few days for other essential metals like $\mathrm{Zn}$ and non-equilibrium for non-essential metals were reported by Spurgeon and Hopkin (1999). The metabolic routes of copper and chromium, however, are different in earthworms. In this study, the fast elimination may indicate that copper is detoxified mainly by excretion, which is supported by Spurgeon and Hopkin (1999). Copper is needed in biochemical reactions as it is part of numerous enzymes (Fisker et al. 2013) transporting substances in cells and tissues but hardly accumulating itself in earthworms (Kennette et al. 2002). Earthworms can regulate copper (Fisker et al. 2011) using metallothionein proteins. $\mathrm{Cu}$ itself is not so active in inducing metallothionein-gene expression, but might need an induction of the protein by other agents, like $\mathrm{Cd}$, to facilitate its binding to earthworm MTs. If metallothioneins are induced by $\mathrm{Cd}$, the $\mathrm{Cu}$ concentrations are higher in earthworms (Mariño et al. 1998). Chromium(VI) is accumulated inside the cell through the same membrane channels used for the transfer of isoelectric and isostructural anions, like $\mathrm{SO}_{4}{ }^{2-}$ and $\mathrm{HPO}_{4}{ }^{2-}$. Glutathione, which is present in high concentrations, plays an important role in the intracellular metabolism of $\mathrm{Cr}(\mathrm{VI})$. There are several mechanisms for $\mathrm{Cr}(\mathrm{VI})$ reduction to $\mathrm{Cr}(\mathrm{III})$ 
via intermediates like $\mathrm{Cr}(\mathrm{V})$ and $\mathrm{Cr}(\mathrm{IV})$ (Codd et al. 2001) by Jurket cells (Shi et al. 1999). In the reduction process, superoxide radicals $\left(\cdot \mathrm{O}_{2}\right), \mathrm{H}_{2} \mathrm{O}_{2}$, and hydroxyl $(\cdot \mathrm{OH})$ radicals, collectively called oxygen species (ROS), play a major role as a messenger for NF-kB activation in Jurket cells (Shi et al. 1999). Environmental concern is triggered by $\mathrm{Cr}(\mathrm{VI})$, which is more mobile and more toxic than $\mathrm{Cr}(\mathrm{III})$ for Eisenia fetida (Sivakumar and Subbhuraam 2005). In the present study, a reduction from $\mathrm{Cr}(\mathrm{VI})$ to $\mathrm{Cr}(\mathrm{III})$ may have happened already in the soils because of their high organic matter contents (Speir et al. 1995).

The bioaccumulation factor (BAF) calculated to estimate metal bioavailability in the different soils was low $(<0.1)$ for $\mathrm{Cr}$ and $\mathrm{Cu}$ due to fast excretion from the earthworms. BAFs for $\mathrm{Cu}$ in E. fetida exposed to different contaminated field soils from UK were higher at 0.18-1.25 (Nahmani et al. 2009). Langdon et al. (2001) determined BAF for $\mathrm{Cu}$ accumulation in L. rubellus exposed to two different soils in UK of 0.060 and 0.049 , which are similar to the values found in the present study. BAF values for $\mathrm{Cr}$ accumulation in $E$. andrei were $0.031-0.047$ when exposed to $\mathrm{Cr}$ in freshly spiked artificial soil (van Gestel et al. 1993). Also, these BAFs are similar to the values measured in the present study.

\section{Uptake-elimination kinetics of arsenic}

In the low (L) contaminated field soil, no uptake of arsenic was seen, with earthworm body concentrations remaining more or less constant at approximately $22 \mathrm{mg} / \mathrm{kg}$ body weight, throughout the uptake and elimination phases. This matches with the low availability of As in this soil seen from $\mathrm{H}_{2} \mathrm{O}$ and $\mathrm{CaCl}_{2}$ extractions (Table 2). Very slow uptake and elimination kinetics were seen in $E$. andrei upon exposure to the medium (M) and high (H) contaminated Hartola field soils, and steadystate was not reached after 21-day exposure. Similar uptake patterns have been reported in field soil (Peijnenburg et al. 1999) and in artificial soils (Lee and Kim 2013). Langdon et al. (2003a) found that L. rubellus eliminated arsenic from their tissues over a 21-day experimental period, which differs from our results. The difference between $L$. rubellus and $E$. fetida/E. andrei may be due to fact that $L$. rubellus from contaminated sites have developed tolerant to arsenic toxicity (Langdon et al. 1999) by developing an efficient arsenic elimination mechanism (Langdon et al. 2003a). Fisher and Koszorus (1992) and Peijnenburg et al. (1999) found no As elimination over an 8-week period in E. fetida, which agrees with the absence of any As elimination in E. andrei in the present study.

Uptake rate constants $k_{1}$ values for As were 0.011 and $0.0065 \mathrm{~kg} \mathrm{soil} / \mathrm{kg}$ worm$/$ day, respectively, which agrees with the $k_{1}$ of $0.0046 \mathrm{~kg}$ soil $/ \mathrm{kg}$ worm/day reported by Peijnenburg et al. (1999) for $E$. andrei exposed to different Dutch field soils. Also, Lee and Kim (2013) found no equilibrium of As uptake and elimination in E. fetida within 28-day exposure. In the present study, elimination rate constants for As were $0.0062 \mathrm{day}^{-1}$ for the medium site and $0.012 \mathrm{day}^{-1}$ for the high site. This slow elimination kinetics is supported by Lee and Kim (2013) and Peijnenburg et al. (1999). As a consequence of the slow elimination, steady-state was not reached within 21 days (Peijnenburg et al. 1999; Lee and Kim 2013), which is in agreement with the results of the present study. GonzálezAlcaraz and van Gestel (2016), however, found that As body concentration of $E$. andrei increased very fast $\left(k_{1}=\right.$ $1.10 \mathrm{~kg} \mathrm{soil} / \mathrm{kg}$ earthworm/day; $20^{\circ} \mathrm{C}$ and $50 \% \mathrm{WHC}$ ), reaching steady-state after 1-3 days of exposure of contaminated soils from a mine tailing. The elimination rate constant $k_{2}=12.7 \mathrm{day}^{-1}\left(20^{\circ} \mathrm{C}\right.$ and $\left.50 \% \mathrm{WHC}\right)$ was much higher than in the present study. This fast kinetics of As is totally opposite to our findings, and is probably due to the different soil types, especially the high $\mathrm{pH}_{\mathrm{CaCl} 2}(6.04-7.44)$ and low organic matter contents $(\sim 1.5-4.3 \%)$ of the soils used in the study of González-Alcaraz and van Gestel (2016).

Earthworms may take up arsenic mainly via the alimentary route (Morgan et al. 1994; Langdon et al. 1999). In earthworm tissues, As is sequestered as As-thiol complexes (Morgan et al. 1994) while also other metal-chelating proteins, metallothioneins (MTs), may be involved in As binding (Langdon et al. 2005) causing its bioconcentration in earthworms (Lee and Kim 2013). Slow excretion of As from $E$. andrei indicates sequestration in less-toxic forms without elimination (Meharg et al. 1998). Fisher and Koszorus (1992) concluded that As may have restricted ability for elimination which also agrees with our results and may explain why As accumulated to $E$. andrei in the present study.

The BAFs for As of 1.8 and 0.54 for the medium and high sites, respectively, show that As is bioaccumulated by E. andrei. Langdon et al. (2001) calculated a very low BAF, suggesting that different earthworm species detoxified As in different ways. Their field soils differed from this study in having low organic matter contents $(1.58-10.02 \%)$ and $\mathrm{pH}\left(\mathrm{H}_{2} \mathrm{O}\right) 4.71-7.18$, while the history of As contamination in the mining area has been very long and As speciation form probably was different from our study. In the mining area, arsenic is accumulated as an arsenobetaine form (Langdon et al. 2005) which is produced by the earthworms upon metabolism of arsenate (Langdon et al. 2003b). The BAF of 0.64 reported by Peijnenburg et al. (1999) for $E$. andrei exposed to Dutch field soils based on steady state concentrations is similar to our data, suggesting As speciation was similar to our soils.

\section{Conclusion}

Little is known about the bioavailability of the metals in the CCA mixture, leading to great uncertainty about the potential risk of CCA-contaminated soils. In this study, we used a 
toxicokinetics approach to assess the bioavailability of copper, chromium, and arsenic to earthworms (Eisenia andrei) in CCA-contaminated field soils. All three metals were available at the site, but the uptake and elimination patterns in E. andrei of $\mathrm{Cr}, \mathrm{Cu}$, and $\mathrm{As}$ were quite different. Uptake and elimination for the essential metals $\mathrm{Cr}$ and $\mathrm{Cu}$ were very fast with equilibrium being reached within 1 day, probably due to active regulation of the body concentrations by the earthworms. For As, uptake and elimination kinetics were very slow leading to relatively high bioaccumulation factors (BAF), suggesting potential risk of metal biomagnification in the food chain. When assessing the ecological risk of CCA-contaminated soils in Hartola, Finland, focus should especially be on the high bioavailability of As, and consider its possible transfer in the food chain. Further research is needed to study the consequences of exposure to multiple metals at this site.

Acknowledgments Open access funding provided by University of Helsinki including Helsinki University Central Hospital. We thank Rudo Verweij, Vrije Universiteit, Amsterdam, for technical assistance and Virve Haili, University of Helsinki, Lahti, for her assistance during the experiments.

Funding information The Onni and Hilja Tuovinen Foundation, Maj and Thor Nessling foundation, the Lahti fund of University of Helsinki, and Lahti Region Development LADEC Ltd. have funded this project.

Open Access This article is distributed under the terms of the Creative Commons Attribution 4.0 International License (http:// creativecommons.org/licenses/by/4.0/), which permits unrestricted use, distribution, and reproduction in any medium, provided you give appropriate credit to the original author(s) and the source, provide a link to the Creative Commons license, and indicate if changes were made.

\section{References}

Allen HE, McGrath SP, McLaughlin MJ, Peijnenburg WJGM, Sauvé S, Lee C (2002) Bioavailability of metals in terrestrial ecosystems: importance of partitioning for bioavailability to invertebrates, microbes, and plants (Metals and the Environmental Series). Society of Environmental Toxicology and Chemistry (SETAC), Pensacola

Atkins G (1969) Multicompartment models for biological systems. Methuen Co. Ltd., London, UK

Balasoiu CF, Zagury GJ, Deschênes L (2001) Partitioning and speciation of chromium, copper, and arsenic in CCA-contaminated soils: influence of soil composition. Sci Total Environ 280:239-255

Cajander A (1949) Forest types and their significance. Acta For Fenn 56: $1-71$

Codd R, Dillon CT, Levina A, Lay PA (2001) Studies on the genotoxicity of chromium: from the test tube to the cell. Coord Chem Rev 216217:537-582

Degryse F, Smolders E, Parker DR (2009) Partitioning of metals (Cd, Co, $\mathrm{Cu}, \mathrm{Ni}, \mathrm{Pb}, \mathrm{Zn}$ ) in soils: concepts, methodologies, prediction and applications - a review. Eur J Soil Sci 60:590-612

Finnish Government decree 214/2007, (2007), http://www.finlex.fi/fi/ laki/smur/2007/20070214\#annettu-saadosten-nojalla, Accessed 19 November 2015
Fisher E, Koszorus L (1992) Sublethal effects, accumulation capacities and elimination rates of $\mathrm{As}, \mathrm{Hg}$ and $\mathrm{Se}$ in the manure worm, Eisenia fetida (Oligochaeta, Lumbricidae). Pedobiologia 16:172-178

Fisker K, Givskov Sørensen J, Damgaard C, Ladegaard K, Holmstrup M (2011) Genetic adaptation of earthworms to copper pollution: is adaptation associated with fitness costs in Dendrobaena octaedra? Ecotoxicology 20:563-573

Fisker K, Holmstrup M, Givskov Sørensen J (2013) Variation in metallothionein gene expression is associated with adaptation to copper in the earthworm Dendrobaena octaedra. Comp Biochem Physiol 157:220-226

González-Alcaraz MN, van Gestel CAM (2016) Metal/metalloid (As, Cd and $\mathrm{Zn}$ ) bioaccumulation in the earthworm Eisenia andrei under different scenarios of climate change. Environ Pollut 215:178-186

Gupta SK, Vollmer MK, Krebs R (1996) The importance of mobile, mobilisable and pseudo total heavy metal fractions in soil for three-level risk assessment and risk management. The Science of the Total Environment 178:11-20

Hagner M, Romantschuk M, Penttinen O-P, Egfors A, Marchandd C, Augustssond A (2017) Assessing toxicity of metal contaminated soil from glassworks sites with a battery of biotests. Sci Total Environ 613-614:30-38

Hingston JA, Collins CD, Murphy RJ, Lester JN (2001) Leaching of chromated copper arsenate wood preservatives: a review. Environ Pollut 111:53-66

ISO (1999) Soil quality inhibition of reproduction of Collembola (Folsomia candida). Geneva $(\mathrm{CH})$ : International Organization for Standardization. ISO guideline 11267

Karjalainen A-M, Kilpi-Koski J, Väisänen AO, Penttinen S, van Gestel CAM, Penttinen O-P (2009) Ecological risks of an old wood impregnation mill: application of triad approach. Integr Environ Assess Manag 5:379-389

Katz SA, Salem H (2005) Chemistry and toxicology of building timbers pressure-treated with chromated copper arsenate: a review. J Appl Toxicol 25:1-7

Kennette D, Hendershot W, Tomlin A, Sauvé S (2002) Uptake of trace metals by the earthworm Lumbricus terrestris, L. in urban contaminated soils. Appl Soil Ecol 19:191-198

Khaodhiar S, Azizian MF, Osathaphan K, Nelson PO (2000) Copper, chromium, and arsenic adsorption and equilibrium modeling an iron-oxide-coated sand, background electrolyte system. Water Air Soil Pollut 119:105-120

Konert M, Vandenberghe J (1997) Comparison of laser grain size analysis with pipette and sieve analysis: a solution for the underestimation of the clay fraction. Sedimentology 44:523-535

Kumpiene J, Lagerkvist A, Maurice C (2008) Stabilization of As, Cr, Cu, $\mathrm{Pb}$ and $\mathrm{Zn}$ in soil using amendments - a review. Waste Manag 28: 215-225

Langdon CJ, Piearce TG, Black S, Semple KT (1999) Resistance to arsenic-toxicity in a population of the earthworm Lumbricus rubellus. Soil Biol Biochem 31:1963-1967

Langdon CJ, Piearce TG, Meharg AA, Semple KT (2001) Resistance to copper toxicity in populations of the earthworms Lumbricus rubellus and Dendrodrilus rubidus from contaminated mine wastes. Environ Toxicol Chem 20:2336-2341

Langdon CJ, Piearce TG, Feldmann J, Semple KT, Meharg AA (2003a) Arsenic speciation in the earthworms Lumbricus rubellus and Dendrodrilus rubidus. Environ Toxicol Chem 22:1302-1308

Langdon CJ, Piearce TG, Meharg AA, Semple KT (2003b) Interactions between earthworms and arsenic in the soil environment: a review. Environ Pollut 124:361-373

Langdon CJ, Winters C, Sturzenbaum SR, Morgan AJ, Charnock JM, Meharg AA, Pierce TG, Lee PH, Semple KT (2005) Ligand arsenic complexation and immunoperoxidase detection of metallothionein in the earthworm Lumbricus rubellus inhabiting arsenic-rich soil. Environ Sci Technol 39:2042-2048 
Lebow S (1996) Leaching of wood preservative components and their mobility in the environment: summary of pertinent literature, General technical report: FPL-GTR-93. U.S. Department of Agriculture, Forest Service, Forest Products Laboratory, Madison, p 36

Leduc F, Whalen JK, Sunahara GI (2008) Growth and reproduction of the earthworm Eisenia fetida after exposure to leachate from wood preservatives. Ecotoxicol Environ Saf 69:219-226

Lee B-T, Kim K-W (2013) Toxicokinetics and biotransformation of As (III) and As (V) in Eisenia fetida. Hum Ecol Risk Assess 19:792-806

Lin ZX, Puls RW (2000) Adsorption, desorption and oxidation of arsenic affected by clay minerals and aging process. Environ Geol 39:753-759

Lukkari T, Taavitsainen M, Väisänen A, Haimi J (2004) Effects of heavy metals on earthworms along contamination gradients in organic rich soils. Ecotoxicol Environ Saf 59:340-348

Maiz I, Arambarri I, Garcia R, Millán E (2000) Evaluation of heavy metal availability in polluted soils by two sequential extraction procedures using factor analysis. Environmental Pollution 110:3-9

Mariño F, Stürzenbaum SR, Kille P, Morgan AJ (1998) Cu-Cd interactions in earthworms maintained in laboratory microcosms: the examination of a putative copper paradox. Comp Biochem Physiol $120: 217-223$

Marinussen MPJC, van der Zee SEATM, de Haan FAM (1997) Effect of $\mathrm{Cd}$ or $\mathrm{Pb}$ addition to $\mathrm{Cu}$-contaminated soil on tissue $\mathrm{Cu}$ accumulation in the earthworm, Dendrobaena veneta. Ecotoxicol Environ Saf 38:309-315

Masscheleyn PH, Delaune RD, Patrick WH Jr (1991) Effect of redox potential and $\mathrm{pH}$ on arsenic speciation and solubility in a contaminated soil. Environ Sci Technol 25:1414-1419

Meharg AA, Shore RF, Broadgate K (1998) Edaphic factors affecting the toxicity and accumulation of arsenate in the earthworm Lumbricus terrestris. Environ Toxicol Chem 17:1124-1131

Morgan AJ, Winters C, Yarwood A (1994) Speed mapping of arsenic distribution in the tissues of earthworms inhabiting arsenious soil. Cell Biol Int 18:911-914

Nahmani J, Hodson ME, Devin S, Vijver MG (2009) Uptake kinetics of metals by the earthworm Eisenia fetida exposed to fieldcontaminated soils. Environ Pollut 157:2622-2628

OECD (1984) Guidelines for the testing of chemicals No. 207, Earthworm acute toxicity tests. Organisation for Economic Cooperation and Development, Paris

OECD (2010) Guidelines for the testing of chemicals No. 317bioaccumulation in terrestrial oligochaetes. Organisation for Economic Co-operation and Development, Paris

Peijnenburg WJGM, Jager T (2003) Monitoring approaches to assess bioaccessibility and bioavailability of metals: matrix issues. Ecotoxicol Environ Saf 56:63-77

Peijnenburg WJGM, Posthuma LHJP, Eijsackers H-JP, Allen HE (1997) A conceptual framework for implementation of bioavailability of metals for environmental management purposes. Ecotoxicol Environ Saf 37:163-172

Peijnenburg WJGM, Baerselman R, de Groot AC, Jager T, Posthuma L, Van Veen RPM (1999) Relating environmental availability to bioavailability: soil-type-dependent metal accumulation in the Oligochaete Eisenia andrei. Ecotoxicol Environ Saf 44:294-310

Pyy O, Haavisto T, Niskala K, Silvola M (2013) Contaminated sites in Finland-review 2013 (in Finnish). Finnish Environment Institute Reports 27/2013. The Finnish Environment Institute, Helsinki

Richardson BA (1993) Wood preservation. E\&F Spon

Sharma V, Sharma R, Satyanarayan S (2011) Biokinetic modeling of heavy metals in earthworms. Toxicol Environ Chem 93:474-486
Shi X, Dong Z, Huang C, Ma W, Liu K, Ye J, Chen F, Leonard SS, Ding M, Castranova V, Valyathan V (1999) The role of hydroxyl radical as a messenger in the activation of nuclear transcription factor NFkB. Mol Cell Biochem 194:63-70

Shrivastava R, Upreti RK, Seth PK, Chaturvedi UC (2002) Effects of chromium on the immune system. FEMS Immunology and Medical Microbiology 34:1-7

Sivakumar S, Subbhuraam CV (2005) Toxicity of chromium(III) and chromium(VI) to the earthworm Eisenia fetida. Ecotoxicol Environ Saf 62:93-98

Smit C, van Beelen P, van Gestel CAM (1997) Development of zinc bioavailability and toxicity for springtail Folsomia candida in an experimentally contaminated field plot. Environ Pollut 98:73-80

Speir TW, Kettles HA, Parshotam A, Searle PL, Vlaar LNC (1995) A simple kinetic approach to derive the ecological dose value, ED50, for the assessment of $\mathrm{Cr}(\mathrm{V} 1)$ toxicity to soil biological properties. Soil Biol Biochem 27:801-810

Spurgeon DJ, Hopkin SP (1995) Extrapolation of the laboratory based OECD earthworm test to metal-contaminated field sites. Ecotoxicology 4:190-205

Spurgeon DJ, Hopkin SP (1999) Comparisons of metal accumulation and excretion kinetics in earthworms (Eisenia fetida) exposed to contaminated field and laboratory soils. Appl Soil Ecol 11:227-243

Spurgeon DJ, Lister L, Kille P, Pereira GM, Wright J, Svendsen C (2011) Toxicokinetic studies reveal variability in earthworm pollutant handling. Pedobiologia 54S:S217-S222

Stilwell DE, Gorny KD (1997) Contamination of soil with copper, chromium, and arsenic under decks built from pressure treated wood. Bull Environ Contam Toxicology 58:22-29

Väisänen A, Suontamo R, Silvonen J, Rintala J (2002) Ultrasound-assisted extraction in the determination of arsenic, cadmium, lead and silver in the contaminated soil samples by inductively coupled plasma atomic emission spectrometry. Anal Bioanal Chem 373:93-97

van Gestel CAM, Hensbergen PJ (1997) Interaction of Cd and Zn toxicity for Folsomia candida Willem (Collembola: Isotomidae) in relation to bioavailability in soil. Environ Toxicol Chem 16:1177-1186

van Gestel CAM, Dirven-Van Breemen EM, Baerselman R (1993) Accumulation and elimination of cadmium, chromium and zinc and effects on growth and reproduction in Eisenia andrei (Oligochaeta, Annelida). Sci Total Environ 134(Supplement 1): 585-597

van Liedekerke M, Prokop G, Rabl-Berger S, Kibblewhite M, Louwagie G (2014) Report EUR 26376 EN. Progress in the management of the contaminated sites in Europe, European Commission: Joint Research Centre Institute for Environment and Sustainability, Publications Office of the European Union. https://ec.europa.eu/ $\mathrm{jrc} / \mathrm{en} /$ publication/reference-reports/progress-managementcontaminated-sites-europe

Viitasaari S (Ed.) (1991) Kyllästämöiden ympäristö ja työturvallisuus. Vesi- ja ympäristöhallituksen julkaisuja, sarja B 11. in Finnish

Vijver M, Vink JPM, Miermans CJH, van Gestel CAM (2003) Oral sealing using glue; a new method to distinguish between intestinal and dermal uptake of metals in earthworms. Soil Biol Biochem 35: $125-132$

Publisher's note Springer Nature remains neutral with regard to jurisdictional claims in published maps and institutional affiliations. 